Szerző:

Dr. K. Plachy Judit Munkahely: Miskolci Egyetem Egészségügyi Kar Fizioterápiás Intézeti Tanszék - adjunktus efkplachy@uni-miskolc.hu Érdeklődési kör: fizikai rekreációs foglalkozások tartása minden korosztály, leginkább a nyugdíjas lakosság számára.

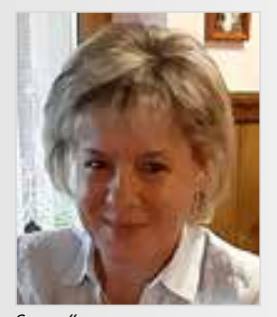

Szerzo":

Füge Ấgnes

A Medicina Komplex Házibeteg Kft. ügyvezetóje és a Medicina a Gyógyulásért Alapítvány Elnöke. Négyéves korában megszületett a célja, hogy gyógyítani szeretne az embereket.

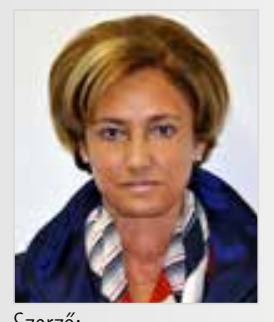

Szerző:

Dr. Kiss-Tóth Emőke

dékán, intézetigazgató főiskolai tanár, Miskolci Egyetem

Egészségügyi Kar Alkalmazott Egészségtudományok Intézete ekdekan@uni-miskolc.hu

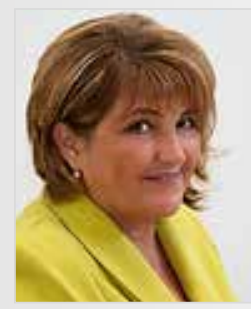

Szerző:

\section{Dr. Rucska Andrea}

oktatási dékánhelyettes, egyetemi docens Miskolci Egyetem Egészségügyi Kar Gyakorlati Módszertani és Diagnosztikai Intézet

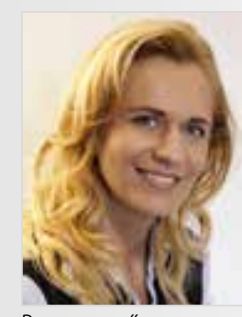

Rovatvezetô:

Kulcsár Kata

\title{
A házibeteg-ellátás kulcsfontosságú szerepe az idős korú betegek gyógyászati szakellátásában
}

\section{Home care plays a key role in the medical care of elderly patients}

BEVEZETÉS, CÉLKITÚZÉS: Az otthoni szakápolás a beteg otthonában vagy tartózkodási helyén, szakorvosi javaslatra és a háziorvos elrendelésére szakképzett ápoló személyzet által végzett tevékenység. CÉL: Megvizsgálni, hogy a 60 éves életkort betöltöttek közül kik veszik igénybe a szolgáltatást és milyen betegséggel kapnak javaslatot a házibeteg-ápolásra, valamint a páciensek milyen társbetegségekkel rendelkeznek. Megvizsgálni, hogy mely szolgáltatást veszik igénybe a páciensek - ápolás, fizioterápia, logopédia, hospice -, ezt milyen eredménnyel, valamint mennyire elégedettek az ellátással.

EREDMENYEK: Vizsgálatunkat 2020. július 1. - október 30. között végeztük Egerben a Medicina Komplex Házibeteg Szolgálat Kft. 60 év fölötti önkéntes betegei körében ( $n=49 ; M=70 e ́ v \pm 10 S D$ ). A kérdőív alapján az alapbetegégek közül első helyen szerepel a perézis $(34,6 \%)$, a magas vérnyomás volt a legjellemzőbb kísérőbetegség (75,5\%). Az érintettek háziorvosuktól értesültek az otthonápolás lehetőségéről (21fő), és leginkább az ápolást és a gyógytornát vették igénybe (16-16 fő).

KÖVETKEZTETES: Az otthonápolás hatékonynak bizonyult, mely meleg családi környezetben valósult meg, szakszerúen, a beteg mihamarabbi rehabilitációja érdekében.

KULCSSZAVAK: házi betegápolás, alap- és kísérő betegségek, szakellátás, betegelégedettség

INTRODUCTION: Home nursing is an activity carried out by qualified nursing staff at the patient's home or place of residence, on the recommendation of a specialist and on the order of a GP.

AIM: Examine which people over the age of 60 use the service and what disease they are recommended for home care. Which service the patients use - nursing, physiotherapy, speech therapy, hospice - with what result and how satisfied they are with the care.

RESULTS: Our study was conducted between July 1 and October 30, 2020 in Eger by the voluntary patients over 60 at Medicina Komplex Home Care Ltd. ( $n=49 ; M=70 \pm 10 S D$ year). According to the questionnaire paresis was the main disease $(34,6 \%)$, hypertension was the outstanding comorbidity $(75,5 \%)$. Those affected learned about the possibility of home care from their GP (21 pc.). Nursing and physiotherapy were the most used (16-16 pc.).

CONCLUSION: Home care has proven to be effective, which was realized in a warm family environment, professionally, in order to rehabilitate the patient.

KEYWORDS: home care, underlying and comorbidity diseases, specialist care, patient satisfaction

\section{BEVEZETÍES}

„A házibeteg-ellátás az egészségügy ellátó struktúrájában, kezelőorvos által elrendelt olyan szakápolók által nyújtott ellátási forma, amely hozzájárul a beteg otthonában vagy tartózkodási helyén az egészségének helyreállításához, állapotának javításához, rehabilitációjához" (Újváriné; Szögi, 2014).

Az 1980-as években az egészségügyet irányító, felügyelő intézmények körében felmerült az elképzelés a házibeteg-ellátás megszervezésének lehetőségéről. Cél a kórházi ágyak csökkentése, a humánusabb betegellátás, az európai uniós elvárásoknak való megfelelés volt. További cél, hogy az idős, önellátásában különböző szinten gátolt betegek otthonukban kapjanak kezelést, mely elősegíti a mútétek utáni rehabilitációt, valamint a már legyengült betegek elláását, melyet kép- zett szakemberek végeznek (Falus; Nemes Szabó, 1999).

1993 és 1994-ben elindult az otthoni szakápolás, melynek finanszírozása a Társadalombiztosítás terhére, meghatározott vizitszám alapján történt (Kárpáti, 2005). Miután ekkor nemrég jött létre a betegellátásnak ez a formája, a betegeknek még csak elképzelésük volt a jobb körülmények közötti gyógyulás, lábadozás lehetőségeiről, mely ápolók, fizioterapeuták, később logopédusok bevonásával múködött. Tény, hogy az otthoni szakápolásba felvett pácienseknél az ápolási idő lecsökkent, az eredmények nagyon pozitívak voltak. Ezért mára már megnőtt az igény erre az ellátásra (Falus; Nemes Szabó, 1999).

Azonban az otthoni szakápolás abban az esetben vehetô igénybe, ha a beteg egészségi állapota - orvosi végzettséghez nem kötött - komplex 
kórházi ápolást igényelne, de azt helyettesíteni lehet az otthoni szakápolás körében nyújtható ellátásokból összeállított kezeléssel (OEP, 2010).

Az 1997. évi CLIV törvény az egészségügyről kimondja, hogy az otthonápolási feladat államilag finanszírozott ellátására akkor van lehetőség, ha az Egészségbiztosító szerződéses viszonyban áll a Szolgáltatóval, és a beteg lakhelye vagy tartózkodási helye a Szolgáltató múködési területére esik. Az otthoni szakápolás rendszerében az ellátás időszaka nem lehet hosszabb, mint az adott betegség miatt szükséges kórházi ápolás időtartama lenne. Egyszerre legfeljebb 14 vizit (napi 1), ami 3 alkalommal meghosszabbítható, egy naptári éven ez 56 alkalmat jelent (NEAK, 202O).

Összességében megállapítható, hogy az otthoni szakápolás a beteg otthonában vagy tartózkodási helyén, szakorvosi javaslatra és a háziorvos elrendelésére szakképzett ápoló személyzet által végzett tevékenység, mely 2005-2006 évben kiegészült a hospice ellátással. Ez először pályázati formában múködött, majd 2008. évtől államilag finanszírozott lett.

Jelen kutatásunkat Egerben a Medicina Komplex Házibeteg Szolgálat Kft. páciensei körében végeztük el 2020. július 1. és október 30. között.

Célunk volt megvizsgálni, hogy a 60 éves életkort betöltöttek közül kik veszik igénybe a szolgáltatást és milyen betegséggel kapnak javaslatot a házibeteg ápolásra, valamint a páciensek milyen társbetegségekkel rendelkeznek. Megvizsgálni, hogy mely szolgáltatást veszik igénybe a páciensek - ápolás, gyógytorna, fizikoterápia, logopédia, hospice -, ezt milyen eredménnyel, valamint mennyire elégedettek az ellátással.

\section{MÓDSZEREK}

A Medicina Komplex Házibeteg Szolgálat Kft. 1996. évben alakult Egerben, azzal a céllal, hogy házibeteg-ellátás keretében segítse az arra rászoruló betegek rehabilitációját, szakápolás keretében javítsa a páciensek életminőségét az orvosi elrendelés alapján. Ezenfelül támogassa a betegek testi, lelki fejlődését, hasznos tanácsokkal lássa el okket a mindennapi tevékenységek önálló elvégzésének érdekében. Az etikai szabályokat betartva tájékoztassa a beteget és a hozzátartozókat a betegség kimeneteléről, a kezelés várható eredményéről. Az ellátás fóképp Egerben múködik, de a szolgáltatás kiterjed Heves megye területére is.

Az otthonápolás mellett 2015. évben megalakult a Medicina a Gyógyulásért Alapítvány, prevenciós és késői reha-

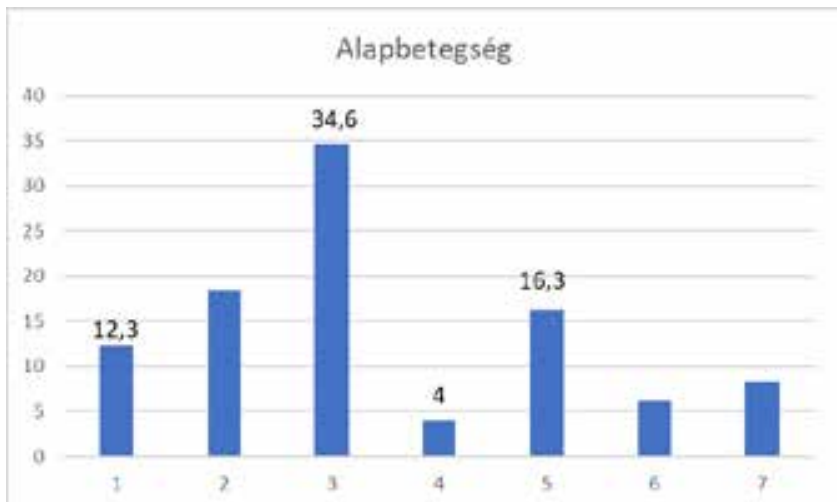

1 ábra: Alapbetegség (\%)

$\mathbf{1}$ csípő TEP; $\mathbf{2}$ térd TEP; $\mathbf{3}$ paresis; $\mathbf{4}$ trauma;

$\mathbf{5}$ tumor; $\mathbf{6}$ Parkinson sy; $\mathbf{7}$ ulcus, decubitus bilitációs céllal. Itt járóbetegekkel foglalkoznak, csoportos foglalkozásokat szerveznek az Egri Civil Kerekasztal Egészségügyi Szekciójának nonprofit szervezeteivel együttmüködve. További tevékenységek az oktatás, az egészségfejlesztés és a szürés (1. kép).

\section{MINTAVÁLASZTÁS}

Mintánkat a Medicina Komplex Házibeteg Kft. 60 év fölötti egri páciensei közül választottuk ki 2020. július 1. és október 30. között egy általunk összeállított önkitöltős kérdőív alapján. A kérdőív 13 db zártvégü és 1 db nyíltvégü kérdést tartalmazott.

A jelentkezők önkéntes alapon vettek részt a kísérletben. Kizáró tényezőnek tekintettük a beszámíthatatlan pszichés állapotot. A kutatás megfelel a Helsinki Nyilatkozat etikai szabályzatának.

Módszer: A kérdőív tartalmazott demográfiai adatokat. Rákérdeztünk az alapbetegségre, a kísérő betegségekre, a házibeteg-ellátással kapcsolatos információkra, valamint a beteg véleményére az ellátással kapcsolatosan.

Az adatokat Microsoft Office Excel 2014 program használatával dolgoztuk fel leíró statisztikával.

\section{EREDMÉNYEK}

A kutatásban 49 fő 60 év fölötti önkéntes vett részt, 29 fó férfi, 20 fó nő (életkor=7O $\pm 10 S D$ ). A mintaelemszám nagyságát befolyásolta az életkor (magasabb, mint 60 év), a megengedett vizitszámkeret és a járványhelyzet.

Első kérdésünk az „Alapbetegség”, melyen azt a betegséget értettük, ami alapján az elrendelést kapta a páciens. $\mathrm{Az}$ 1. diagramon látható, hogy legnagyobb számban paretikus betegeket kezeltünk (34,6\%). Ezt követték a totál endoprotézis (TEP) beültetések. Csípő TEP (12,3\%), térd TEP (18,4\%).

Nem meglepő módon a paretikus tünetekkel rendelkező betegek érték el a legnagyobb értéket, hiszen ennek kialakulása esetünkben nagyrészt neurológiai kórkép (Parkinson sy., Stroke), trauma és tumor volt. Az ízületi arthrózis gyakori elváltozás idős korban, ezért magas a TEP mútétek száma.

„Milyen kísérőbetegségei vannak?” kérdésre több válaszlehetőséget is meg lehetett jelölni. Ebben az esetben a magas vérnyomás $(75,5 \%)$ volt a mérvadó, melyet a koleszterinszint emelkedése $(46,9 \%)$ és a korábbi TEP beültetések követtek (csípő 38,7\%; térd 20,4\%). (2. ábra).

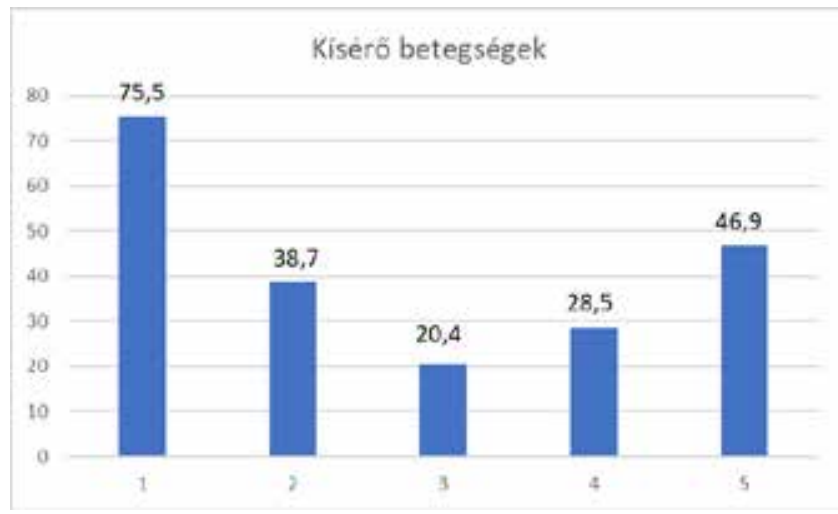

2. ábra: Kísérő betegségek (\%)

$\mathbf{1}$ hipertónia; $\mathbf{2}$ korábbi csípő TEP; $\mathbf{3}$ korábbi térd TEP; 4 diabétesz; 5 magas koleszterin 
Itt is bizonyítható, hogy a Magyarországon vezető haláloknak számító szív- és érrendszeri betegségek kialakulásának okozói a magas vérnyomás, a magas koleszterin és a diabétesz emelkedettek.

Következőleg arra kérdeztünk rá, hogy „Ki javasolta a házibeteg-ellátás lehetőségét?”. Elsődlegesen a háziorvos 21 főnél, majd a kórházi kezelőorvos 17 esetben szerepelt (3. ábra).

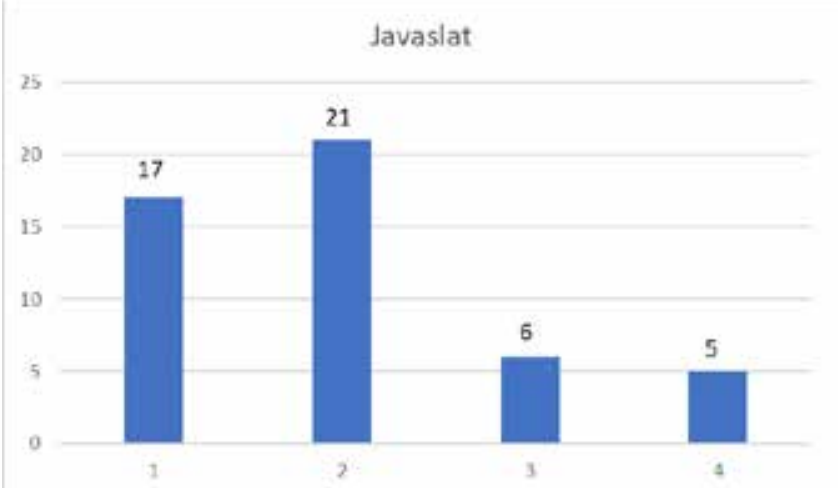

3. ábra: Ki javasolta a házi betegápolást? (db)

1 kórházi kezelőorvos; 2 háziorvos; 3 körzeti ápolónő; $\mathbf{4}$ ismerős

Várható volt ez az eredmény, hiszen az egészségügyi ellátás jelen formáját a kórházi kezelőorvos javasolja és a háziorvos rendeli el.

„A házibeteg-ellátás mely formáját veszi igénybe?” kérdésnél egyformán a szakápolás és a gyógytorna vezet (16-16 fónél) (4. ábra).

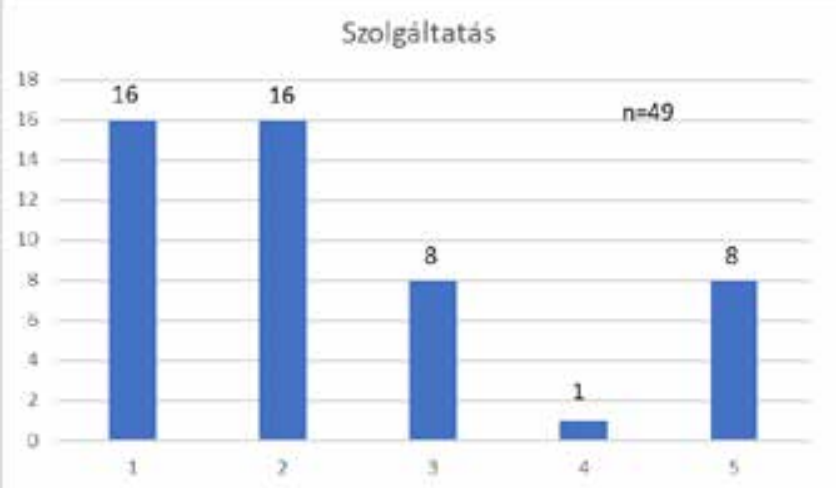

4. ábra: Milyen szolgáltatást vett igénybe? (db)

1 szakápolás; 2 gyógytorna; 3 fizikoterápia; $\mathbf{4}$ logpédia; 5 hospice

Mint az „Alapbetegségekből” kiderül, pácienseink legnagyobb része paretikus volt. Ők gyógytorna kezelésre szorulnak, a daganatos betegek és a sebekkel, decubitussal rendelkezők pedig szakápolást kaptak.

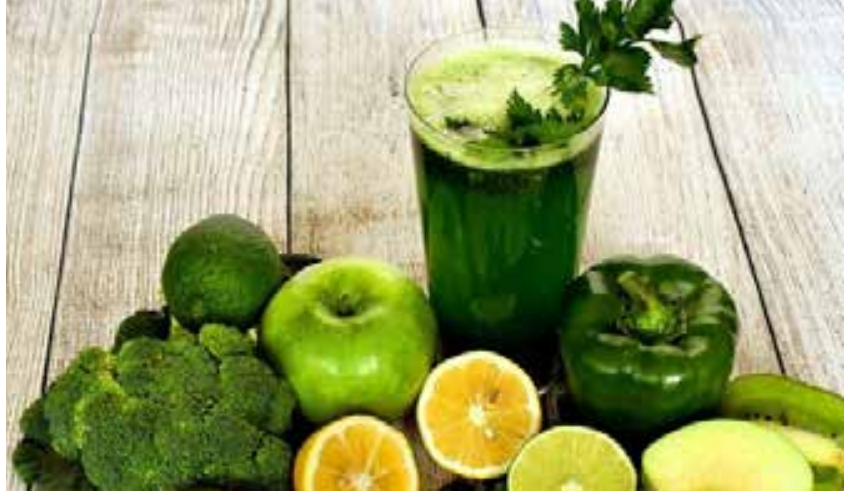

Kezeltjeink nagy többsége teljesen elégedett volt tevékenységünkkel. Az otthonápolás tekintetében előnyben részesítették, hogy meleg, családi környezetben biztosítottuk számukra a betegségüknek megfelelő, egyéni, szakszerü ellátást.

\section{KÖVETKEZTETÉSEK}

Bizonyított tény, hogy a Magyarországon vezető halálokként első helyen szerepelnek a szív- és érrendszeri-; a mozgásszervrendszeri és a daganatos betegségek ( $K S H, 2016)$. Jelen kutatásunkban mintaelemszámunk ugyan kicsi, de bizonyíthatóak az előbbiekben megfogalmazott demográfiai adatok, ugyanis az „Alapbetegségek” és a „Kísérőbetegségek" esetében láthatjuk a magas vérnyomást, az emelkedett koleszterinszintet és a daganatos megbetegedéseket.

Ezek a kóros értékek okozhatnak Stroke-ot is, melyből gyakran alakul ki a parézis. A TEP műtétek gyakorisága a mozgásszervrendszeri elváltozásokra utal.

Hazai és nemzetközi szakirodalmakban sok tudományos cikket találunk az otthonápolásról, azonban a betegek véleményét érintően kevés adatot olvashatunk.

Kutatási eredményeinket támasztja alá Lovácsi (2014) betegelégedettségi mérése, ami azt bizonyítja, hogy a betegek 34\%-ban a háziorvostól, 28\%-ban a kórházi kezelőorvostól értesültek az otthonápolás lehetőségéről. Ami érdekesség, hogy az érintettek 27\%-ban információt kaptak a szociális ellátó szervektől is.

Egy másik dolgozatban (Mihucz, 2018) a következő, kapcsolódó eredményt találtuk, miszerint a gyógytorna-elrendelés oka házi betegellátásban elsősorban csípő- vagy térdprotézis (30\%), majd ezt követik a krónikus betegségek (23\%).

Összességében elmondható, hogy a népbetegségek megjelennek az általunk vizsgált mintában. Ezenfelül örömteli, hogy az ápolt betegek hasznosnak vélik az otthonukban, meleg családi környezetben végzett szakszerü, a gyógyulásukat segítő ápolási tevékenységet.

További vélemény még, hogy fontos a meghitt, családias környezetben történő gyógyítás, melyben a beteg testi, lelki egészségére egyénileg figyel az ellátó, akit sok esetben szinte „családtagnak” tekint az ellátott és a környezete.

Mihucz, G. (2018): Gyógytorna az otthonápolásban. Szakdolgozat, Miskolci Egyetem Egészségügyi Kar, 1-79.

Nemzeti Egészségbiztosítási Alapkezelő NEAK közlönyállapot (1999): Magyar joganyagok - 43/1999. (III. 3.) Korm. rendelet - az egészségügyi szolgáltatások Egészségbiztosítási Alapból történő finanszírozásának részletes szabályairól, 1-65.

Országos Egészségpénztár (2010): Otthoni szakápolás. 2010.01, www.oep.hu [Letöltve: 2020. november 2.]

Újváriné, S.A., Szögi, N. (2014): Közösségi ápolás. Debreceni Egyetem Egészségügyi Kar, https://regi.tankonyvtar.hu/hu/tartalom/tamop412A/2010_0020_kozossegi_magyar/13_az_otthoni_szakpols_keretben_vgezhet_tevkenysgek_kre.html [Letöltve: 2020. október 20.] 